\title{
Role of the bed nucleus of the stria terminalis in aversive learning and memory
}

\author{
Travis D. Goode and Stephen Maren \\ Institute for Neuroscience and the Department of Psychology, Texas A\&M University, College Station, Texas 77843-3474, USA
}

\begin{abstract}
Surviving threats in the environment requires brain circuits for detecting (or anticipating) danger and for coordinating appropriate defensive responses (e.g., increased cardiac output, stress hormone release, and freezing behavior). The bed nucleus of the stria terminalis (BNST) is a critical interface between the "affective forebrain"-including the amygdala, ventral hippocampus, and medial prefrontal cortex-and the hypothalamic and brainstem areas that have been implicated in neuroendocrine, autonomic, and behavioral responses to actual or anticipated threats. However, the precise contribution of the BNST to defensive behavior is unclear, both in terms of the antecedent stimuli that mobilize BNST activity and the consequent defensive reactions. For example, it is well known that the BNST is essential for contextual fear conditioning, but dispensable for fear conditioning to discrete conditioned stimuli (CSs), at least as indexed by freezing behavior. However, recent evidence suggests that there are circumstances in which contextual freezing may persist independent of the BNST. Furthermore, the BNST is involved in the reinstatement (or relapse) of conditioned freezing to extinguished discrete CSs. As such, there are critical gaps in understanding how the BNST contributes to fundamental processes involved in Pavlovian fear conditioning. Here, we attempt to provide an integrative account of BNST function in fear conditioning. We discuss distinctions between unconditioned stress and conditioned fear and the role of BNST circuits in organizing behaviors associated with these states. We propose that the BNST mediates conditioned defensive responses-not based on the modality or duration of the antecedent threat or the duration of the behavioral response to the threat-but rather as consequence the ability of an antecedent stimulus to predict when an aversive outcome will occur (i.e., its temporal predictability). We argue that the BNST is not uniquely mobilized by sustained threats or uniquely involved in organizing sustained fear responses. In contrast, we argue that the BNST is involved in organizing fear responses to stimuli that poorly predict when danger will occur, no matter the duration, modality, or complexity of those stimuli. The concepts discussed in this review are critical to understanding the contribution of the human BNST to fear and anxiety disorders.
\end{abstract}

The bed nucleus of the stria terminalis (BNST) is a diverse cluster of neuronal nuclei located within the ventral forebrain of humans and other animals (Dumont 2009). The connectivity of the bilateral BNST (or sometimes BST) is extensive and far-reaching-the BNST is interconnected with the amygdala, dorsal raphe, hippocampus, hypothalamus, medulla, nucleus accumbens, periaqueductal gray, prefrontal cortex, thalamus, ventral tegmental area, among others (for recent reviews, see Avery et al. 2016; Lebow and Chen 2016). As a result of this connectivity, it is perhaps not surprising that the BNST has been implicated in a number of functions and behaviors relevant to psychiatric disorders, including the acquisition and expression of Pavlovian fear conditioning, reinstatement of drug seeking, negative affect in pain, compulsivity, the expression of social defeat and learned helplessness, social attachment and reproductive behaviors, and regulation of the stress axis (Davis et al. 2010; Hammack et al. 2012; Crestani et al. 2013; Petrulis 2013; Adhikari 2014; Coria-Avila et al. 2014; Stamatakis et al. 2014; Takahashi 2014; Fox et al. 2015; Kash et al. 2015; Minami and Ide 2015; Avery et al. 2016; Daniel and Rainnie 2016; Gungor and Paré 2016; Lebow and Chen 2016; Mantsch et al. 2016; Waraczynski 2016; Laman-Maharg and Trainor 2017; Vranjkovic et al. 2017). Moreover, a growing body of research links BNST function (and its dysfunction) to a number of human pathological disorders such as anxiety and addiction (Fox et al. 2015; Avery et al. 2016; Lebow and Chen 2016)—disorders that

\section{Corresponding author: maren@tamu.edu}

Article is online at http://www.learnmem.org/cgi/doi/10.1101//m.044206.116. are widespread, extremely costly to the individual, and often comorbid (Kessler et al. 2005a,b; Koob 2009; McEwen 2012; Whiteford et al. 2013; DiLuca and Olesen 2014; Gonzalez and Martinez 2014). Accordingly, the BNST represents an important target for therapeutic interventions aimed at treating various psychopathologies.

Within the realm of aversively motivated behaviors, early studies suggested a limited role of the BNST in fear conditioning to only certain stimulus modalities (e.g., LeDoux et al. 1988). It has been suggested that temporal factors (either in terms of the duration of the antecedent stimulus or consequent behavioral response) explain BNST's selective function in learned fear (e.g., Davis et al. 2010). Further, it is now understood that different populations of neurons within the BNST can bidirectionally regulate various unlearned anxiety-like responses (Jennings et al. 2013; Kim et al. 2013; Crowley et al. 2016; Marcinkiewcz et al. 2016; Mazzone et al. 2016). Despite this progress, we still lack an updated and integrated view of BNST function that accounts for its diverse contributions to aversive learning and memory. Accordingly, the purpose of this review is to dissect the current literature in an effort to provide a cohesive analysis of BNST function in Pavlovian fear

\footnotetext{
(C) 2017 Goode and Maren This article is distributed exclusively by Cold Spring Harbor Laboratory Press for the first 12 months after the full-issue publication date (see http://learnmem.cshlp.org/site/misc/terms.xhtml). After 12 months, it is available under a Creative Commons License (AttributionNonCommercial 4.0 International), as described at http://creativecommons. org/licenses/by-nc/4.0/.
} 
conditioning and how this might relate to its roles in stress- and anxiety-like behaviors. While this review focuses primarily on animal studies, we also examine recent and relevant developments in human BNST research. We will begin by addressing the fundamentals of aversive learning, followed by a review of the BNST's relationship with other conditioned fear-regulating regions of the brain. In subsequent sections, we will address the role of the BNST in the conditioning and expression of fear in detail. Finally, we will consider how these results may be unified under an updated model of conditioned fear-related BNST function. Based on a growing and converging data set, we argue that an overarching function of the BNST in humans and other animals is to generate defensive behaviors to unpredictable threats independent of their modality or duration.

\section{Learning to fear}

Pavlovian conditioning is the process through which animals learn associations between stimuli (Pavlov 1927). For aversive events, Pavlovian fear conditioning models how humans and other animals learn about threats in their environment (Rescorla 1988; LeDoux 2000; Maren 2001; Phelps and LeDoux 2005). Importantly, the conditioning, extinction, and relapse of fear may contribute to and interact with trauma-related psychopathologies such as posttraumatic stress disorder (PTSD) (Jovanovic and Ressler 2010; Mahan and Ressler 2012; Milad and Quirk 2012; Goswami et al. 2013; Gonzalez and Martinez 2014; VanElzakker et al. 2014; Careaga et al. 2016; also, see LeDoux 2012, 2014, 2017; LeDoux and Pine 2016; LeDoux and Brown 2017).

In specific terms, Pavlovian fear conditioning is a process through which a salient cue (e.g., a tone or light source) is paired with an unavoidable and noxious outcome (e.g., electric shock). Exposure to the shock (the unconditioned stimulus, or US) induces various species-specific "circa-strike" defensive responses (termed unconditioned responses) (e.g., escape, defensive fighting, etc.; Bolles 1970; Bolles and Fanselow 1980; Fanselow 1980, 1994). Through the process of conditioning, the cue comes to predict the aversive outcome (hence, termed the conditioned stimulus, or CS), and with one or more pairings with the US, a "postencounter" conditioned response (e.g., freezing and autonomic activity in rodents) to the CS alone emerges. In addition to freezing in the presence of a shock-paired CS, animals will suppress instrumental responses for food (a phenomenon termed conditioned suppression; e.g., Waddell et al. 2006, 2008) and will increase the magnitude of their startle responses to other loud acoustic stimuli (termed fear-potentiated startle; e.g., Lee and Davis 1997). In humans, conditioned fear is often indexed using physiological measures, including skin conductance, heart rate, and pupil dilation (Lonsdorf et al. 2017). Fear conditioning can occur in the absence of a discrete CS (the US is "unsignaled"); in this case, the environment or "context" serves as the CS (and is referred to as contextual conditioning; Rudy et al. 2004; Curzon et al. 2009; Maren et al. 2013; Urcelay and Miller 2014). Standard conditioning procedures to a discrete CS often result in at least some concurrent contextual conditioning as the discrete CS may not fully acquire all of the associative strength of the US (Rescorla and Wagner 1972).

In contrast to conditioning, repeated presentations of the CS in the absence of the US will ultimately lead to a reduction in conditional responding, a process termed extinction (Pavlov 1927; Myers and Davis 2002; Chang et al. 2009). Numerous studies indicate that extinction results in a new inhibitory memory that suppresses conditional fear in a context-dependent manner (Maren 2011). Specifically, fear to an extinguished CS will return when that CS is presented outside of the extinction context, a fundamental form of "relapse" termed renewal (Bouton and Bolles 1979a).
Renewal is not the only way in which fear can relapse: fear reinstates after reexposure to the US (Rescorla and Heth 1975; Bouton and Bolles 1979b; Bouton and King 1983; Westbrook et al. 2002; Morris et al. 2005; Goode et al. 2015a) and fear can spontaneously recover after a passage of time in the absence of the CS (Pavlov 1927; Rescorla 2004). Distinct mechanisms are thought to underlie these and other various forms of relapse (and are examined elsewhere in detail: Bouton 2002, 2004; Vervliet et al. 2013; Goode and Maren 2014; Haaker et al. 2014; McConnell and Miller 2014; Maren and Holmes 2016), but it should be noted that contextual information is thought to be critical for many of these phenomena (Bouton et al. 2006).

\section{Neural circuits for aversive learning and memory}

Originally considered a subregion of the "extended amygdala" (Johnson 1923; Alheid and Heimer 1988; Alheid et al. 1998; Alheid 2003), the BNST has numerous direct connections with other areas of the brain that are involved in Pavlovian fear conditioning, including the amygdala, hippocampus, and prefrontal cortex (PFC). Brain circuits for the acquisition and expression of conditioned fear as well as for its extinction and relapse have received considerable attention over the years (Fendt and Fanselow 1999; LeDoux 2000; Maren 2001; Maren and Quirk 2004; Quirk and Mueller 2008; Herry et al. 2010; Orsini and Maren 2012; Furini et al. 2014; Izquierdo et al. 2016). In brief, CS and US signals converge on the lateral nucleus (LA) of the amygdala and plasticity within this nucleus is vital for the acquisition, consolidation, and expression of conditioned fear (Rogan et al. 1997; Maren 1999a, 2005; Johansen et al. 2011). Output from the amygdala, via the central nucleus of the amygdala (CeA), targets downstream structures such as the periaqueductal gray (PAG) and hypothalamus to engage freezing and stress responses (respectively) in the presence of conditioned cues (LeDoux et al. 1988; Behbehani 1995; McLemore et al. 1999; Keifer et al. 2015; Tovote et al. 2015). Additionally, the hippocampus-by way of its connections with the PFC and amygdala-fundamentally regulates the acquisition and expression of contextual fear in a time-dependent manner (Kim and Fanselow 1992; Phillips and LeDoux 1992; Maren et al. 1998, 2013; Fanselow 2000; Fanselow and Dong 2010; Xu et al. 2016). Furthermore, PFC has been shown to drive or impair extinction via its projections to fear-promoting or -inhibiting neurons within the amygdala (Vertes 2004; Quirk et al. 2006; Hoover and Vertes 2007; Herry et al. 2008; Knapska et al. 2012; Senn et al. 2014; Adhikari et al. 2015; Rozeske et al. 2015; Giustino and Maren 2015; Gourley and Taylor 2016)—processes that are regulated by the hippocampus (Ji and Maren 2007, 2015a,b; Goosens 2011; Maren et al. 2013; Orsini et al. 2011; Xu et al. 2016).

The BNST is well positioned to integrate information from the amygdala, hippocampus, and PFC (Weller and Smith 1982; Sun et al. 1991; Canteras and Swanson 1992; McDonald et al. 1999; Dong et al. 2001a; Reynolds and Zahm 2005; Jalabert et al. 2009; deCampo and Fudge 2013; Torrisi et al. 2015; Lebow and Chen 2016; Oler et al. 2017; Reichard et al. 2017), and BNST subregions may have differential roles in this process (for recent reviews, see Lebow and Chen 2016; Gungor and Paré 2016). Nevertheless, the functions of these circuits in fear conditioning are not well characterized. BLA activity appears to be required for BNST-dependent fear behaviors in most cases, insofar as BLA lesions block both phasic and long-lasting fear responses even with the BNST intact (Maren et al. 1996; Maren 1999b; Davis et al. 2010; but, see overtraining studies: Poulos et al. 2010; Zimmerman and Maren 2011). However, it is not yet clear if neurons required for BNST-dependent or -independent conditioned fears are distinct 
or overlapping within the BLA (Davis et al. 2010). Furthermore, it is unclear if direct projections from the BLA are required for BNST-dependent aversive learning and memory, particularly because photostimulation of these afferents produces nonassociative anxiolytic effects (Kim et al. 2013; Crowley et al. 2016).

The CeA also densely innervates the BNST, but the role of the CeA in BNST-dependent defensive behaviors has been an area of debate. There is evidence that these structures mediate different aspects of conditioned fear (Walker and Davis 2008; Walker et al. 2009; Davis et al. 2010), although others have suggested that their roles in these processes are similar (Fox et al. 2015; Gungor and Paré 2016; Shackman and Fox 2016, also, see Gorka et al. 2017). That said, there are some recent and compelling data indicating that the CeA is required for BNST-dependent conditioned fears. For example, Asok and colleagues (2017) demonstrated that optogenetic silencing of central amygdala CRF-positive afferents in the BNST during training blunts fear expression to a shock-associated context, at least in the later portion of the retrieval (note that it is possible that other circuits may be involved and at different stages). The anxiogenic functions of the BNST are generally attributed to its anterior regions, (see Crown et al. 2000; KochoSchellenberg et al. 2014) a region targeted by CeA (and BLA) neurons (Gungor and Paré 2016).

Beyond the amygdala, the significance of hippocampal inputs to the BNST in the context of aversive learning is not well understood. The hippocampus exerts inhibitory control over stress hormone release (via the hypothalamic-pituitary-adrenal [HPA] axis) through its glutamatergic projections to the BNST (Cullinan et al. 1993; Forray and Gysling 2004). Thus, projections from the hippocampus to the BNST may modulate anxiety (and perhaps BNST-dependent fear) not by driving defensive responses per se but by reducing stress responses in particular contexts (Glangetas et al. 2017; also, see Gorka et al. 2017). The PFC, particularly the infralimbic (IL) region of the PFC, projects strongly to the BNST -this circuit (along with BNST-projecting cells from the neighboring orbitofrontal cortex) may be involved in both reward (Jalabert et al. 2009; Reisiger et al. 2014) and threat processing (Spencer et al. 2005; Fox et al. 2010; Motzkin et al. 2015). Nonetheless, a role for IL projections to the BNST in conditioned fear has not been explored. The prelimbic (PL) region of the PFC has been shown to play important roles in contextual conditioning (e.g., Corcoran and Quirk 2007; Ye et al. 2017), but its direct projections to the BNST are sparse. Outside of these circuits, recent work on serotonergic inputs to the BNST has implicated dorsal raphe afferents in enhanced fear conditioning (Marcinkiewcz et al. 2016).

BNST efferents extensively target the CeA, but moderately to sparsely terminate in the PFC, BLA, and hippocampus (Dong et al. 2000, 2001b, Dong and Swanson 2003, 2004a,b, 2006a,b,c; Gungor et al. 2015; Krüger et al. 2015; Dabrowska et al. 2016; Kaufling et al. 2017; Oler et al. 2017); little is known regarding the roles of these circuits in aversive memories. BNST efferents are largely GABAergic, with a smaller portion consisting of glutamatergic neurons (Tovote et al. 2015; Vranjkovic et al. 2017; also, see McElligott et al. 2013; Avery et al. 2014; Kaufling et al. 2017). BNST subregions are highly interconnected (Turesson et al. 2013), suggesting that BNST-dependent behavioral responses reflect an integration of activity within these areas (Kim et al. 2013; Gungor and Paré 2016). Outside of its connections with the amygdala, PFC, and hippocampus, the BNST is positioned to elicit defensive behavior via direct projections to the hypothalamus and PAG (Holstege et al. 1985; Gray and Magnuson 1992; Nagy and Paré 2008). Finally, it is worth noting that in humans (Allen and Gorski 1990; Chung et al. 2002) and rodents (Hines et al. 1985; Hines et al. 1992), the male BNST is generally larger than in females (also, see Avery et al. 2014). It is not yet clear if this sexual dimorphism impacts BNST function in aversive learning, but (perhaps re- latedly) male rodents generally express greater levels of contextual (but not discretely cued) freezing when compared with females (Maren et al. 1994; Markus and Zecevic 1997; Pryce et al. 1999; Gupta et al. 2001; Barker and Galea 2010; Nagaya et al. 2015; Acca et al. 2017; Bangasser and Wicks 2017; also, see Gruene et al. 2015; Pellman et al. 2017). With these connections in mind, we will now explore the various factors that may account for the roles of the BNST in conditioned fear.

\section{BNST function in response to unconditioned aversive stimuli}

Exposure of animals to aversive events-including both physical (e.g., unsignaled footshock, restraint) and psychological stressors (e.g., open or elevated spaces, bright lights, predator odors, alarm pheromones)_readily engage or influence signaling within the BNST (Rosen et al. 2015; Daniel and Rainnie 2016; Gungor and Paré 2016). Currently, it is understood that BNST neurons do not react uniformly to these various stressful stimuli. For example, the BNST has been shown to exhibit alterations (albeit, increases or decreases depending on the study) in immediate early gene expression in its anterolateral and anteroventral regions after restraint alone, inescapable tailshock, or predator odor (Lino-de-Oliveira et al. 2001; Day et al. 2005; Christianson et al. 2011; Butler et al. 2016). Electrophysiological studies have further shown that aversive footshock exposure can rapidly recruit and modify activity in BNST neurons (Marcinkiewcz et al. 2016; also, see Daldrup et al. 2016). In turn, BNST lesions often reduce or eliminate the behavioral and physiological changes (termed unconditioned fear responses) that come with direct exposure to these aversive stimuli. For example, BNST lesions block freezing responses in the presence of predator odors (Fendt et al. 2003, 2005). Additionally, stress (in the form of extensive footshock exposure) can potentiate acoustic startle in a separate context; lesions of the BNST block this effect (Gewirtz et al. 1998; also, see Hammack et al. 2004; Meloni et al. 2006). In cases where BNST lesions fail to alter unconditioned stress responses (e.g., Treit et al. 1998), it is thought that this may be due to the disruption of both stress-promoting and -attenuating circuits within the BNST (Adhikari 2014; Luyck and Luyten 2015). Nevertheless, the BNST functions, in part, to generate unconditioned stress responses and to mediate stress-induced sensitization.

Along these lines, BNST manipulations can also induce unconditioned stress and fear- or anxiety-like responses in a subregionspecific and neurotransmitter system-dependent manner (Levita et al. 2004; Hammack et al. 2009b; Daniel and Rainnie 2016). For example, increasing CRF, calcitonin gene-related peptide (CGRP), or serotonin signaling within the BNST can potentiate acoustic startle in the absence of any other training, and tends to increase anxiety in other tasks in the short term (Lee and Davis 1997; Sahuque et al. 2006; Lee et al. 2008; Sink et al. 2011, 2013b; Mazzone et al. 2016). Similarly, $\beta$-adrenergic agonism in the BNST or induction of pituitary adenylate cyclase-activating polypeptide (PACAP) signaling within the BNST promotes stress and anxiety-like responses (Deyama et al. 2008; Hammack et al. 2009a, 2010; Naka et al. 2013; Hammack and May 2015). Increasing nitric oxide production within the BNST has also been shown to induce unconditioned freezing in a novel arena (Faria et al. 2016; also, see Deyama et al. 2017). Furthermore, stimulation or inhibition of select BNST circuits, including BLA $\rightarrow$ BNST and $\mathrm{BNST} \rightarrow$ VTA neurons, can increase or decrease avoidance (or modulate stress responding) without any prior learning (Jennings et al. 2013; Kim et al. 2013; Crowley et al. 2016; Marcinkiewcz et al. 2016; Mazzone et al. 2016). 
Stress may lead to plasticity in the BNST that will ultimately affect circuit function during future stressors or tasks. For example, acute restraint stress significantly alters plasticity in the BNST in response to PFC-dependent input (Glangetas et al. 2013). Chronic stress in the form of multiday unpredictable shock exposure generally increases serotonin release in the BNST and alters serotonin receptor expression in the BNST (Hazra et al. 2012). Additionally, it has been shown that stress-enhancement of trace eyeblink conditioning in rats (through the use of restraint and tail shock) is mediated by the BNST (Bangasser et al. 2005; Bangasser and Shors 2008). From a translational perspective, and in light of pathologies in which patients may have experienced a significant degree of stress, these data are important to consider when examining unconditioned anxiety- and (perhaps) conditioned fear-related function in the BNST. Indeed, circuit-specific manipulations often occur in animals where stress history is minimal (Belzung et al. 2014). As such, important questions remain as to whether the effects seen in the circuit-selective studies (Jennings et al. 2013; Kim et al. 2013; Crowley et al. 2016; Marcinkiewcz et al. 2016; Mazzone et al. 2016) remain true following a history of stress and whether plasticity in the BNST shifts the phenotypic function of any of these circuits (also, see Conrad et al. 2011). In total, the BNST processes unconditioned aversive stimuli, but it is important to consider that negative outcomes may occur in a distinct place and in the presence of particular cues, which may foster associative learning.

\section{BNST function in fear conditioning: stimulus modality and duration}

BNST lesions (whether permanent or temporary) do not universally blunt somatic, autonomic, or hormonal responses during fear conditioning. Rather, several studies have now demonstrated a necessary role for the BNST in the learning and/or expression of contextual-but not discretely cued-fear, as indexed by freezing, conditioned suppression, potentiated startle, and stress hormone release (LeDoux et al. 1988; Hitchcock and Davis 1991; Lee and Davis 1997; Gewirtz et al. 1998; Sullivan et al. 2004; Waddell et al. 2006; Resstel et al. 2008; Duvarci et al. 2009; Poulos et al. 2010; Zimmerman and Maren 2011; Hott et al. 2012, 2017; Sink et al. 2013a; Davis and Walker 2014; Goode et al. 2015b; Hammack et al. 2015; Asok et al. 2016). Relatedly, electrical stimulation of the BNST can either increase or decrease conditioned contextual fear (as assessed by freezing or startle amplitude), effects that depend on the location, intensity, and frequency of the stimulation (Luyck et al. 2017; also, see Baas et al. 2014; Luyck and Luyten 2015). Disrupting BNST signaling does not appear to impair discrimination between two nonaversive contexts per se (e.g., given the persistence of context-dependent renewal in BNST-lesioned animals in the study by Goode et al. 2015b), suggesting that contextual representations (e.g., spatial/visual properties, etc.) are processed upstream of the BNST in the hippocampus. It has not yet been demonstrated whether unconditional fearand stress-attenuating circuits of the BNST (Jennings et al. 2013; Kim et al. 2013; Crowley et al. 2016; Marcinkiewcz et al. 2016; Mazzone et al. 2016) (or BNST neurons in general) play any fundamental role in the extinction of conditioned fear to cues or contexts (also, see Ranjan et al. 2017).

Some of the aforementioned studies involved pretraining permanent lesions of the BNST, making it difficult to determine whether the BNST's role in context fear is specific to acquisition, consolidation, expression, or some combination of these processes (granted, there are few studies published that specifically examine the role of the BNST in the acquisition or consolidation of fear). However, there are a handful of studies using temporary or post- training lesions (or inhibitors of protein synthesis) that implicate BNST function in the acquisition (Davis and Walker 2014; also, see Asok et al. 2017), consolidation (Poulos et al. 2010), and expression of context fear (Sullivan et al. 2004; Zimmerman and Maren 2011; Goode et al. 2015b; but, see Davis and Walker 2014). Consistent with these ideas, cued or contextual conditioning increases immediate early gene expression (e.g., c-fos) in the BNST (Passerin et al. 2000; Ranjan et al. 2017), as does the expression of contextual fear (Beck and Fibiger 1995; also, see Luyten et al. 2012). Furthermore, the BNST has been shown to be important for consolidation of contextual fear in overtrained animals if the BLA is lesioned (this consolidation effect is eliminated if the BLA remains intact; Poulos et al. 2010; Zimmerman and Maren 2011). These effects on acquisition and consolidation suggest that BNST afferents (e.g., Asok et al. 2017) or perhaps BNST neurons themselves are at least in part a node for BNST-dependent fear memory in certain cases. However, overtraining studies suggest that the BNST is not an alternative locus for standard fear conditioning (Poulos et al. 2010; Zimmerman and Maren 2011). Thus, it is not yet clear whether plasticity within the BNST serves to store BNST-dependent conditioned fear memories and/or if the BNST is simply recruited by learning-dependent plasticity in other regions in the presence of particular conditioned stimuli. Collectively, these findings suggest a unique role for the BNST in contextual fear conditioning, but why the BNST is selective for contextual fear is unclear.

Conditioned contexts and discrete CSs not only differ in terms of their modality, but they also often differ in duration. To determine which factor is more relevant to BNST function, Hammack et al. (2015) tested whether the duration of context exposure prior to US onset in a context conditioning procedure influenced the role of the BNST in the task. Specifically, Hammack et al. (2015) placed rats in a context where unsignaled footshock occurred either 1 or $10 \mathrm{~min}$ after animals entered the chamber. Rats were removed from the chambers $30 \mathrm{sec}$ after shock offset (thereby, the groups differed on both the timing of shock onset as well as total context exposure). After several training sessions, rats were tested in the absence of shock to the context. The results revealed that contextual fear was only affected by the BNST lesions in the context in which shock occurred at a 10-min delay; rats with BNST lesions conditioned normally to the context in which shock occurred at a 1-min delay. Importantly, these data suggest that contextual fear can be independent of the BNST under some conditions (which may also have interesting implications for context fear-induced reinstatement). Consistent with these findings, an earlier report by Waddell et al. (2006) demonstrated that lesions of the BNST attenuated conditioned suppression in the presence of a long-duration (10 min), but not a short-duration (1 min), auditory CS. Based on these results, the authors (Waddell et al. 2006; Hammack et al. 2015) argued that it was stimulus duration, not modality or response duration, that determined whether the BNST was recruited during fear conditioning procedures.

However, stimulus duration alone may not fully account for the recruitment of the BNST during fear conditioning. For example, BNST lesions prevent fear reinstatement to short-duration CSs (Waddell et al. 2006, 2008; Goode et al. 2015b). Likewise, shock-induced reinstatement of extinguished fear to a discrete CS is associated with increased activity in the human BNST (Scharfenort and Lonsdorf 2016). Furthermore, BNST lesions can enhance discrimination between a CS+ and CS- (Duvarci et al. 2009; Radke 2009) by attenuating fear to the CS- (also, see Botta et al. 2015; De Bundel et al. 2016; Sanford et al. 2017). Thus, the BNST may also be involved in the generalization of conditioned fear to both discrete cues and contexts (also, see Jasnow et al. 2017). Similarly, serotonin in the BNST during training to a phasic CS has been shown to increase fear responding to that same CS 
when tested off-drug in a familiar but different context (Ravinder et al. 2013; however, it is unclear if these effects are confounded by enhanced contextual fear on top of the tone response at test; also, see Marcinkiewcz et al. 2016). In total, there are many circumstances in which the BNST regulates fear to unimodal or even discrete stimuli.

\section{BNST function in fear conditioning: response duration}

Early and seminal research on the role of downstream targets of the BLA in aversive learning demonstrated a double dissociation in the roles of the BNST and CeA in sustained and phasic fear responses, respectively (Lee and Davis 1997; Walker and Davis 1997; but, see Sullivan et al. 2004). In particular, CRF- and unconditioned lightenhanced startle-paradigms associated with long-duration fearlike responses-were shown to be mediated by the BNST (and not the CeA); conversely, fear-potentiated startle, which involves a phasic CS-evoked fear response, was attenuated by CeA lesions (and not the BNST) (Lee and Davis 1997). In this framework, the BNST was argued to be necessary to maintain long-lasting fear responses, whereas the CeA drives rapid, phasic fear responses (Davis 1998, 2006; Davis and Shi 1999; Walker et al. 2009; Davis et al. 2010; Rodríguez-Sierra et al. 2016; also, see Herrmann et al. 2016; Brinkmann et al. 2017a).

Nevertheless, a growing body of evidence indicates that the BNST mediates both rapid and sustained fear responses at least in some cases (also, see Nagy and Paré 2008). For example, work in humans has revealed that the BNST can exhibit rapid and short-lived neural responses to phasic images of an approaching tarantula or to relatively brief unpredictable threats of shock (Mobbs et al. 2010; Choi et al. 2012; Klumpers et al. 2015; Shackman and Fox 2016; also, see Schlund et al. 2013). At the behavioral level, posttraining lesions or inactivation of the BNST rapidly attenuate freezing responses to an aversive context (e.g., as early as within the first minute; Zimmerman and Maren 2011; Goode et al. 2015b) — these effects coincide with rapid prevention of reinstatement to the onset of discrete extinguished CSs. Other studies examining the effects of various neuromodulators or neurosteroids within the BNST have also shown rapid alterations in behavioral responding upon return to a conditioned context (Nagaya et al. 2015; Acca et al. 2017). At the physiological level, Resstel et al. (2008) demonstrated that blockade of neurotransmitter release within the BNST (via the infusion of cobalt chloride) prevented the immediate increase in mean arterial pressure and heart rate that coincided with being placed in a previously conditioned context. IntraBNST administration of NMDA antagonists or nNOS inhibitors also blocks these rapid physiological changes (Hott et al. 2017). These data suggest that the BNST does not selectively mediate sustained fear responses.

\section{BNST function in fear conditioning: state-dependence}

Recently, it has been observed that intra-BNST infusions of the neurosteroid allopregnanolone (ALLO, a progesterone metabolite that potentiates $\mathrm{GABA}_{\mathrm{A}}$ receptors) produce state-dependent retention deficits of contextual fear (Nagaya et al. 2015; Acca et al. 2017). In other words, animals trained or tested after ALLO infusions exhibit impaired contextual freezing, however animals trained and tested after ALLO infusions exhibit robust freezing. This suggests that the BNST not only processes environmental (i.e., exteroceptive) conditioned contexts, but might also be involved in representing interoceptive contexts (such as hormonal states). Moreover, state-dependence is not observed when ALLO is infused into the BLA, suggesting that the effects of ALLO on state- dependence relates to its actions within the BNST (Acca et al. 2017). However, it is not yet clear if other drugs that are commonly used to assess BNST function also induce state-dependence via the BNST, or if other brain areas might mediate these state-dependent effects. For example, infusions of NBQX (an AMPA receptor antagonist) or muscimol (a GABA receptor agonist) into the BNST did not cause renewal of fear to an extinguished CS as might be expected if there was a drug-induced shift in the animals interoceptive context (i.e., interoceptive renewal; Goode et al. 2015b). Nevertheless, when examining the role of the BNST in conditioned fear, it is important to consider the role of interoceptive contexts that may be associated with the aversive event; a change in interoceptive context might induce state-dependent generalization decrements.

\section{Temporal unpredictability in BNST-dependent aversive learning and memory}

Up to this point, we have reviewed studies that suggest that the BNST (1) is particularly attuned to aversive (US-like) stimuli, (2) is implicated in acquisition, expression, reinstatement, and at times consolidation of conditioned fear, (3) does not mediate all forms of contextual fear, (4) mediates fear to unimodal or multimodal stimuli, (5) can respond to phasic or sustained cues, (6) can exhibit phasic or sustained neural responses in the presence of threats, (7) may be involved in aversive learning to interoceptive states, and (8) can rapidly mediate defensive behaviors. What unifies these properties and what may account for BNST's selectivity in fear conditioning? We propose that the BNST is specifically recruited to aversive learning by temporally unpredictable events (Fig. 1).

By this view, the BNST is not involved in aversive contextual conditioning or expression per se, rather it becomes engaged by stimuli (whether cues or exteroceptive/interoceptive contexts) that are associated with temporally unpredictable USs (even if the probability that the US will occur is $100 \%$ ). In other words, the BNST is recruited when the animal cannot reliably predict the onset of shock. This account of BNST function explains its diverse roles in conditioning to stimuli of various modalities or durations. For example, the BNST mediates fear to long CSs (whether unimodal or multimodal) because long CSs are poor predictors of when the aversive US will occur during presentation of the stimulus (e.g., Waddell et al. 2006; Hammack et al. 2015; also, see Fig. 1E, $\mathrm{G})$. Conversely, discrete CSs (whether contexts or cues) that are trained with near immediate shock (Fig. 1A,B) allow the animal to reliably predict US onset and thereby do not require the BNST. However, the BNST is required for conditioning to relatively short, unimodal CSs if those CSs are trained as poor predictors of when a US occurs (Fig. 1C; Lange et al. 2016). This interpretation of BNST function is perhaps specific to its role in aversive learning-that is, temporal uncertainty of a US may foster BNST-dependence to various CSs, whereas nonassociative stressors (serving as USs) may engage the BNST for reasons not necessarily related to timing. Nevertheless, time as a factor in unconditioned stress is plausible (e.g., bright lights may signal a degree of vulnerability during which the animal is uncertain of the time in which a direct threat or predator will appear), but such possibilities are still in need of exploration.

One possibility is that unpredictable threats operate to produce sustained fear as the animal has learned that the risk of US onset is nearly continuous throughout presentation of the CS-these sustained fear responses have been argued to require the BNST (e.g., Walker and Davis 2008; Walker et al. 2009; Davis et al. 2010). However, temporally predictable CSs (albeit, massed) or contexts (e.g., Hammack et al. 2015) can also produce long-lasting and sustained fear responses, such as freezing behaviors, that do 

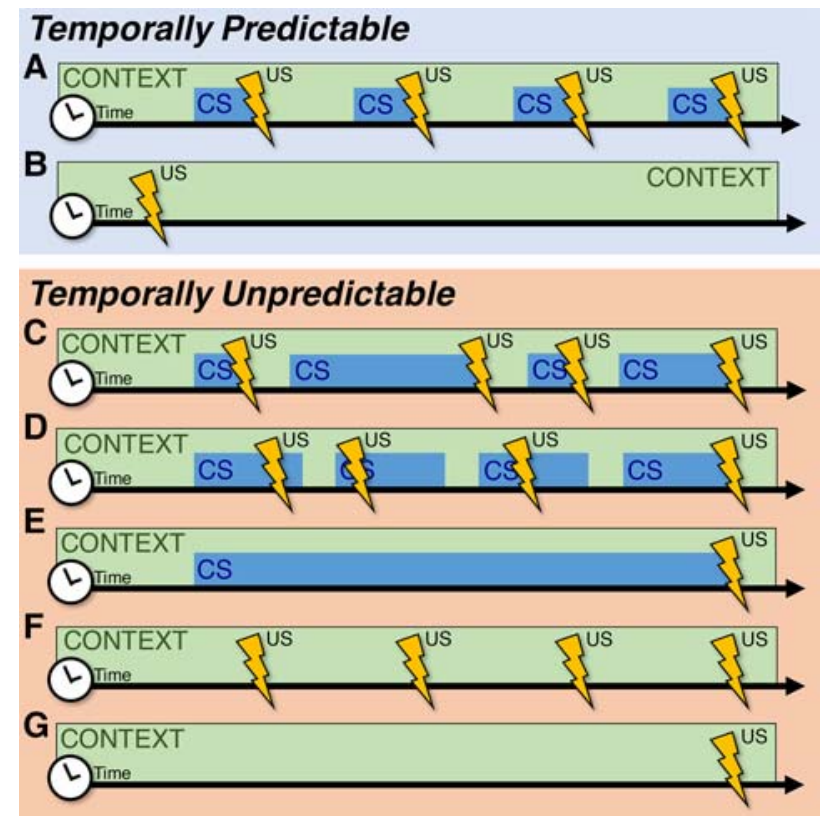

Figure 1. Temporally predictable and unpredictable aversive conditioning procedures. Standard fear conditioning procedures produce temporally predictive discrete CSs that do not require the BNST-fear to the conditioning context may be BNST-dependent given that the context is a poor predictor of shock onset $(A)$. Contextual conditioning with early - but not necessarily immediate-shock onset, however, is temporally predictive of the US, and may therefore be BNST-independent (this procedure may require multiple training sessions and may not necessarily require extensive context exposure post-shock) $(B)$. Temporally unpredictable conditioned stimuli can be generated by varying the duration of the CS across conditioning trials $(C)$, randomizing the onset of shock during presentation of a CS $(D)$, extending the duration of the CS to exhibit remote shock onset $(E)$, or conditioning a context with multiple unsignaled and temporally unpredictive shocks $(F)$ or late shock onset $(G)$. BNST circuitry has been implicated in all of these cases of temporally unpredictable aversive stimuli (outside of example $D$, which has not yet been tested).

not require the BNST (e.g., Zimmerman and Maren 2011). Hence, it is possible that neither the duration of the fear response nor the duration of the CS is the determinant of when or whether the BNST is recruited to mediate conditioned fear responses.

Of course, there is considerable variability in animals and individuals in terms of how accurately they time the onset of aversive events (also, see Buhusi and Meck 2005). Thus, the role of the BNST in temporal predictability may need to be addressed by comparing responses to temporally predictable (Fig. $1 \mathrm{~A}, \mathrm{~B}$ ) and unpredictable antecedents of aversive outcomes (Fig. 1C-E). The number of studies utilizing temporally uncertain discrete CSs are limited (e.g., Daldrup et al. 2015; Lange et al. 2016; Seidenbecher et al. 2016), but they often train the CS with components of both immediate and delayed US onset (thereby contributing to its temporal uncertainty). Fear to these stimuli is then tested to a continuous presentation of the CS over the course of several minutes. Only the late phases of CS presentation appear to require the BNST (Davis et al. 2010; also, see Meloni et al. 2006). Accordingly, we argue that in these cases these early phases of retrieval are akin to temporally predictable CSs, whereas the later times of CS exposure are temporally unpredictable of US onset. By training the CS with early shock onset (as well as late onset), the animals have learned that CS onset could possibly predict immediate shock-only after sustaining the CS does the uncertainty arise regarding when the US might occur. Along these lines, if the CS is paired with temporally certain shock (i.e., early shock onset), its retrieval is BNST-independent and does not elicit sustained responding. Thus, we propose that temporal uncertainty, which may produce sustained fear, accounts for the BNST's diverse contributions to aversive learning and memory. Note that other forms of unpredictability-such as CS-US contingency (e.g., Davies and Craske 2015) — might also interact with temporal unpredictability (also, see Alvarez et al. 2011; Robinson et al. 2012; Schmitz and Grillon 2012).

It is not yet clear if the conditioning of temporally uncertain stimuli relies on plasticity within and/or upstream of the BNST, but recent studies comparing predictable and unpredictable threats have implicated the amygdala (e.g., Herry et al. 2007), amygdalar afferents to the BNST, and activity/endocannabinoid signaling within the BNST itself in the response to temporally unpredictable threats (Davis et al. 2010; Lange et al. 2016). Additionally, pharmacological or optogenetic inhibition of the dorsal hippocampus has been shown to attenuate fear to temporally unpredictable (but not predictable) auditory CSs (e.g., Fig. 1D; Amadi et al. 2017)—manipulations that also disrupt contextual fear.

In total, we propose that the BNST mediates learned fear when the timing of an aversive event is uncertain, even in the face of certainty that the event will happen. Indeed, this interpretation is consistent with other recent accounts of BNST broader functions. For example, the BNST has been proposed to be involved in "valence surveillance" (Lebow and Chen 2016), which includes monitoring positive and negative stimuli and initiating appropriate behavioral and physiological reactions. Unpredictable stressors (such as temporally unpredictable CSs) may require ongoing monitoring via the BNST-such hypervigilance to threat of shock has been associated with activity in the BNST in anxious humans (Somerville et al. 2010). Ultimately, the role of the BNST in mediating fear responses to temporally unpredictable threats is likely an important factor in the role of the BNST in human anxiety, given that ambiguity is thought to be a core component of anxiety (Foa et al. 1992; Bouton et al. 2001; Grillon 2002a,b, 2008; Perusini and Fanselow 2015). Notably, there have been several recent advances in imaging techniques of the human BNST, which will help to better characterize the role of the BNST in aversive learning and in clinical psychopathologies (Fox et al. 2015; Torrisi et al. 2015; Avery et al. 2016; Brinkmann et al. 2017a,b; Pedersen et al. 2017; Sladky et al. 2017; Theiss et al. 2017). On a final note, an emphasis on temporal uncertainty might have implications for BNST's additional roles in drug seeking behaviors (Shaham et al. 2003; Flavin and Winder 2013; Silberman and Winder 2013), given that footshock exposure can induce both fear and drug reinstatement (e.g., Erb and Stewart 1999; Erb et al. 2001; Shalev et al. 2001). All of this considered, future experiments will hopefully shed light on the precise circumstances and circuits by which conditioned and unconditioned stimuli engage the BNST.

\section{Acknowledgments}

This work was supported by grants from the National Institute of Mental Health (R01MH065961 to S.M. and F31MH107113 to T.D.G.), and a McKnight Foundation Memory and Cognitive Disorders Award to S.M.

\section{References}

Acca GM, Mathew AS, Jin J, Maren S, Nagaya N. 2017. Allopregnanolone induces state-dependent fear via the bed nucleus of the stria terminalis. Horm Behav 89: 137-144.

Adhikari A. 2014. Distributed circuits underlying anxiety. Front Behav Neurosci 8: 112 .

Adhikari A, Lerner TN, Finkelstein J, Pak S, Jennings JH, Davidson TJ, Ferenczi E, Gunaydin LA, Mirzabekov JJ, Ye L, et al. 2015. Basomedial amygdala mediates top-down control of anxiety and fear. Nature 527: 179-185. 
Alheid GF. 2003. Extended amygdala and basal forebrain. Ann N Y Acad Sci 985: $185-205$.

Alheid GF, Heimer L. 1988. New perspectives in basal forebrain organization of special relevance for neuropsychiatric disorders: the striatopallidal, amygdaloid, and corticopetal components of substantia innominata. Neuroscience 27: 1-39.

Alheid GF, Beltramino CA, de Olmos JS, Forbes MS, Swanson DJ, Heimer L. 1998. The neuronal organization of the supracapsular part of the stria terminalis in the rat: the dorsal component of the extended amygdala. Neuroscience 84: 967-996.

Allen LS, Gorski RA. 1990. Sex difference in the bed nucleus of the stria terminalis of the human brain. J Comp Neurol 320: 697-706.

Alvarez RP, Chen G, Bodurka J, Kaplan R, Grillon C. 2011. Phasic and sustained fear in humans elicits distinct patterns of brain activity. Neuroimage 55: 389-400.

Amadi U, Lim SH, Liu E, Baratta MV, Goosens KA. 2017. Hippocampal processing of ambiguity enhances fear memory. Psychol Sci 28: 143-161.

Asok A, Schulkin J, Rosen JB. 2016. Corticotropin releasing factor type-1 receptor antagonism in the dorsolateral bed nucleus of the stria terminalis disrupts contextually conditioned fear, but not unconditioned fear to a predator odor. Psychoneuroendocrinology 70: $17-24$.

Asok A, Draper A, Hoffman AF, Schulkin J, Lupica CR, Rosen JB. 2017. Optogenetic silencing of a corticotropin-releasing factor pathway from the central amygdala to the bed nucleus of the stria terminalis disrupts sustained fear. Mol Psychiatry doi: 10.1038/mp.2017.79.

Avery SN, Clauss JA, Winder DG, Woodward N, Heckers S, Blackford JU. 2014. BNST neurocircuitry in humans. Neuroimage 91: 311-323.

Avery SN, Clauss JA, Blackford JU. 2016. The human BNST: functional role in anxiety and addiction. Neuropsychopharmacology 41: 126-141.

Baas JM, Klumpers F, Mantione MH, Figee M, Vulink NC, Schuurman PR, Mazaheri A, Denys D. 2014. No impact of deep brain stimulation on fear-potentiated startle in obsessive-compulsive disorder. Front Behav Neurosci 8: 305.

Bangasser DA, Shors TJ. 2008. The bed nucleus of the stria terminalis modulates learning after stress in masculinized but not cycling females. Neurosci 28: 6383-6387.

Bangasser DA, Wicks B. 2017. Sex-specific mechanisms for responding to stress. J Neurosci Res 95: 75-82.

Bangasser DA, Santollo J, Shors TJ. 2005. The bed nucleus of the stria terminalis is critically involved in enhancing associative learning after stressful experience. Behav Neurosci 119: 1459-1466.

Barker JM, Galea LA. 2010. Males show stronger contextual fear conditioning than females after context pre-exposure. Physiol Behav 99: 82-90.

Beck CH, Fibiger HC. 1995. Conditioned fear-induced changes in behavior and in the expression of the immediate early gene c-fos: with and without diazepam pretreatment. J Neurosci 15: 709-720.

Behbehani MM. 1995. Functional characteristics of the midbrain periaqueductal gray. Prog Neurobiol 46: 575-605.

Belzung C, Turiault M, Griebel G. 2014. Optogenetics to study the circuits of fear- and depression-like behaviors: a critical analysis. Pharmacol Biochem Behav 122: 144-157.

Bolles RC. 1970. Species-specific defense reactions and avoidance learning. Psychol Rev 77: 32-48.

Bolles RC, Fanselow MS. 1980. PDR-a multi-level model of fear and pain. Behav Brain Sci 3: 315-323.

Botta P, Demmou L, Kasugai Y, Markovic M, Xu C, Fadok JP, Lu T, Poe MM, $\mathrm{Xu}$ L, Cook JM, et al. 2015. Regulating anxiety with extrasynaptic inhibition. Nat Neurosci 18: 1493-1500.

Bouton ME. 2002. Context, ambiguity, and unlearning: sources of relapse after behavioral extinction. Biol Psychiatry 52: 976-986.

Bouton ME. 2004. Context and behavioral processes in extinction. Learn Mem 11: 485-494.

Bouton ME, Bolles RC. 1979a. Contextual control of the extinction of conditioned fear. Learn Motiv 10: 445-466.

Bouton ME, Bolles RC. 1979b. Role of conditioned contextual stimuli in reinstatement of extinguished fear. J Exp Psychol Anim Behav Process 5: 368-378.

Bouton ME, King DA. 1983. Contextual control of the extinction of conditioned fear: tests for the associative value of the context. J Exp Psychol Anim Behav Process 9: 248-265.

Bouton ME, Mineka S, Barlow DH. 2001. A modern learning theory perspective on the etiology of panic disorder. Psychol Review 108: 4-32.

Bouton ME, Westbrook RF, Corcoran KA, Maren S. 2006. Contextual and temporal modulation of extinction: behavioral and biological mechanisms. Biol Psychiatry 60: 352-360.

Brinkmann L, Buff C, Feldker K, Tupak SV, Becker MPI, Herrmann MJ, Straube T. 2017a. Distinct phasic and sustained brain responses and connectivity of amygdala and bed nucleus of the stria terminalis during threat anticipation in panic disorder. Psychol Med. doi: 10.1017/ S0033291717001192.
Brinkmann L, Buff C, Neumeister P, Tupak SV, Becker MP, Herrmann MJ, Straube T. 2017b. Dissociation between amygdala and bed nucleus of the stria terminalis during threat anticipation in female post-traumatic stress disorder patients. Hum Brain Mapp 38: 2190-2205.

Buhusi CV, Meck WH. 2005. What makes us tick? Functional and neural mechanisms of interval timing. Nat Rev Neurosci 6: 755-765.

Butler RK, Oliver EM, Sharko AC, Parilla-Carrero J, Kaigler KF, Fadel JR, Wilson MA. 2016. Activation of corticotropin releasing factor-containing neurons in the rat central amygdala and bed nucleus of the stria terminalis following exposure to two different anxiogenic stressors. Behav Brain Res 304: 92-101.

Canteras NS, Swanson LW. 1992. Projections of the ventral subiculum to the amygdala, septum, and hypothalamus: a PHAL anterograde tract-tracing study in the rat. J Comp Neurol 324: 180-194.

Careaga MB, Girardi CE, Suchecki D. 2016. Understanding posttraumatic stress disorder through fear conditioning, extinction and reconsolidation. Neurosci Biobehav Rev 71: 48-57.

Chang CH, Knapska E, Orsini CA, Rabinak CA, Zimmerman JM, Maren S. 2009. Fear extinction in rodents. Curr Protoc Neurosci Chapter 8: Unit 8.23.

Choi JM, Padmala S, Pessoa L. 2012. Impact of state anxiety on the interaction between threat monitoring and cognition. Neuroimage 59: 1912-1923.

Christianson JP, Jennings JH, Ragole T, Flyer JG, Benison AM, Barth DS, Watkins LR, Maier SF. 2011. Safety signals mitigate the consequences of uncontrollable stress via a circuit involving the sensory insular cortex and bed nucleus of the stria terminalis. Biol Psychiatry 70: 458-464.

Chung WC, De Vries GJ, Swaab DF. 2002. Sexual differentiation of the bed nucleus of the stria terminalis in humans may extend into adulthood. $J$ Neurosci 22: 1027-1033.

Conrad KL, Louderback KM, Gessner CP, Winder DG. 2011. Stress-induced alterations in anxiety-like behavior and adaptations in plasticity in the bed nucleus of the stria terminalis. Physiol Behav 104: 248-256.

Corcoran KA, Quirk GJ. 2007. Activity in prelimbic cortex is necessary for the expression of learned, but not innate, fears. J Neurosci 27: 840-844

Coria-Avila GA, Manzo J, Garcia LI, Carrillo P, Miquel M, Pfaus JG. 2014. Neurobiology of social attachments. Neurosci Biobehav Rev 43: 173-182.

Curzon P, Rustay NR, Browman KE. 2009. Cued and contextual fear conditioning in rodents. In Methods of behavior analysis in neuroscience, 2nd edition (ed. Buccafusco JJ), Chapter 2. CRC Press, Boca Raton.

Crestani CC, Alves FH, Gomes FV, Resstel LB, Correa FM, Herman JP. 2013. Mechanisms in the bed nucleus of the stria terminalis involved in control of autonomic and neuroendocrine functions: a review. Curr Neuropharmacol 11: 141-159.

Crowley NA, Bloodgood DW, Hardaway JA, Kendra AM, McCall JG, Al-Hasani R, McCall NM, Yu W, Schools ZL, Krashes MJ, et al. 2016. Dynorphin controls the gain of an amygdalar anxiety circuit. Cell Rep 14: $2774-2783$

Crown ED, King TE, Meagher MW, Grau JW. 2000. Shock-induced hyperalgesia. III. Role of the bed nucleus of the stria terminalis and amygdaloid nuclei. Behav Neurosci 114: 561-573.

Cullinan WE, Herman JP, Watson SJ. 1993. Ventral subicular interaction with the hypothalamic paraventricular nucleus: evidence for a relay in the bed nucleus of the stria terminalis. J Comp Neurol 332: 1-20.

Dabrowska J, Martinon D, Moaddab M, Rainnie DG. 2016. Targeting corticotropin-releasing factor projections from the oval nucleus of the bed nucleus of the stria terminalis using cell-type specific neuronal tracing studies in mouse and rat brain. J Neuroendocrinol 28. doi: 10.1111/jne.12442.

Daldrup T, Remmes J, Lesting J, Gaburro S, Fendt M, Meuth P, Kloke V, Pape HC, Seidenbecher T. 2015. Expression of freezing and fear-potentiated startle during sustained fear in mice. Genes Brain Behav 14: $281-291$.

Daldrup T, Lesting J, Meuth P, Seidenbecher T, Pape HC. 2016. Neuronal correlates of sustained fear in the anterolateral part of the bed nucleus of stria terminalis. Neurobiol Learn Mem 131: 137-146.

Daniel SE, Rainnie DG. 2016. Stress modulation of opposing circuits in the bed nucleus of the stria terminalis. Neuropsychopharmacology 41: $103-125$.

Davies CD, Craske MG. 2015. Psychophysiological responses to unpredictable threat: effects of cue and temporal unpredictability. Emotion 15: 195-200.

Davis M. 1998. Are different parts of the extended amygdala involved in fear versus anxiety? Biol Psychiatry 44: 1239-1247.

Davis M. 2006. Neural systems involved in fear and anxiety measured with fear-potentiated startle. Am Psychol 61: 741-756.

Davis M, Shi C. 1999. The extended amygdala: are the central nucleus of the amygdala and the bed nucleus of the stria terminalis differentially involved in fear versus anxiety? Ann N Y Acad Sci 877: 281-291.

Davis M, Walker DL. 2014. Role of bed nucleus of the stria terminalis and amygdala AMPA receptors in the development and expression of 
context conditioning and sensitization of startle by prior shock. Brain Struct Funct 219: 1969-1982.

Davis M, Walker DL, Miles L, Grillon C. 2010. Phasic vs sustained fear in rats and humans: role of the extended amygdala in fear vs anxiety. Neuropsychopharmacology 35: 105-135.

Day HE, Nebel S, Sasse S, Campeau S. 2005. Inhibition of the central extended amygdala by loud noise and restraint stress. Eur J Neurosci 21: $441-454$.

De Bundel D, Zussy C, Espallergues J, Gerfen CR, Girault JA, Valjent E. 2016. Dopamine D2 receptors gate generalization of conditioned threat responses through mTORC1 signaling in the extended amygdala. Mol Psychiatry 21: 1545-1553.

deCampo DM, Fudge JL. 2013. Amygdala projections to the lateral bed nucleus of the stria terminalis in the macaque: comparison with ventral striatal afferents. J Comp Neurol 521: 3191-3216.

Deyama S, Katayama T, Ohno A, Nakagawa T, Kaneko S, Yamaguchi T, Yoshioka M, Minami M. 2008. Activation of the $\beta$-adrenoceptor-protein kinase A signaling pathway within the ventral bed nucleus of the stria terminalis mediates the negative affective component of pain in rats. $J$ Neurosci 28: 7728-7736.

Deyama S, Sugano Y, Mori S, Amano T, Yoshioka M, Kaneda K, Minami M. 2017. Activation of the NMDA receptor-neuronal nitric oxide synthase pathway within the ventral bed nucleus of the stria terminalis mediates the negative affective component of pain. Neuropharmacology 118: $59-68$.

DiLuca M, Olesen J. 2014. The cost of brain diseases: a burden or a challenge? Neuron 82: 1205-1208.

Dong HW, Swanson LW. 2003. Projections from the rhomboid nucleus of the bed nuclei of the stria terminalis: implications for cerebral hemisphere regulation of ingestive behaviors. J Comp Neurol 463: 434-472.

Dong HW, Swanson LW. 2004a. Organization of axonal projections from the anterolateral area of the bed nuclei of the stria terminalis. J Comp Neurol 468: 277-298.

Dong HW, Swanson LW. 2004b. Projections from bed nuclei of the stria terminalis, posterior division: implications for cerebral hemisphere regulation of defensive and reproductive behaviors. J Comp Neurol 471: 396-433.

Dong HW, Swanson LW. 2006a. Projections from bed nuclei of the stria terminalis, dorsomedial nucleus: implications for cerebral hemisphere integration of neuroendocrine, autonomic, and drinking responses. $J$ Comp Neurol 494: 75-107.

Dong HW, Swanson LW. 2006b. Projections from bed nuclei of the stria terminalis, magnocellular nucleus: implications for cerebral hemisphere regulation of micturition, defecation, and penile erection. J Comp Neurol 494: $108-141$.

Dong HW, Swanson LW. 2006c. Projections from bed nuclei of the stria terminalis, anteromedial area: cerebral hemisphere integration of neuroendocrine, autonomic, and behavioral aspects of energy balance. $J$ Comp Neurol 494: 142-178.

Dong H, Petrovich GD, Swanson LW. 2000. Organization of projections from the juxtacapsular nucleus of the BST: a PHAL study in the rat. Brain Res 859: $1-14$

Dong HW, Petrovich GD, Swanson LW. 2001a. Topography of projections from amygdala to bed nuclei of the stria terminalis. Brain Res Brain Res Rev 38: 192-246.

Dong HW, Petrovich GD, Watts AG, Swanson LW. 2001b. Basic organization of projections from the oval and fusiform nuclei of the bed nuclei of the stria terminalis in adult rat brain. J Comp Neurol 436: $430-455$.

Dumont EC. 2009. What is the bed nucleus of the stria terminalis? Prog Neuropsychopharmacol Biol Psychiatry 33: 1289-1290.

Duvarci S, Bauer EP, Paré D. 2009. The bed nucleus of the stria terminalis mediates inter-individual variations in anxiety and fear. J Neurosci 29: 10357-10361.

Erb S, Stewart J. 1999. A role for the bed nucleus of the stria terminalis, but not the amygdala, in the effects of corticotropin-releasing factor on stress-induced reinstatement of cocaine seeking. J Neurosci 19: RC35.

Erb S, Salmaso N, Rodaros D, Stewart J. 2001. A role for the CRF-containing pathway from central nucleus of the amygdala to bed nucleus of the stria terminalis in the stress-induced reinstatement of cocaine seeking in rats. Psychopharmacology (Berl) 158: 360-365.

Fanselow MS. 1980. Conditional and unconditional components of post-shock freezing. Pavlov J Biol Sci 15: 177-182.

Fanselow MS. 1994. Neural organization of the defensive behavior system responsible for fear. Psychon Bull Rev 1: 429-438.

Fanselow MS. 2000. Contextual fear, gestalt memories, and the hippocampus. Behav Brain Res 110: 73-81.

Fanselow MS, Dong HW. 2010. Are the dorsal and ventral hippocampus functionally distinct structures? Neuron 65: 7-19.
Faria MP, Miguel TT, Gomes KS, Nunes-de-Souza RL. 2016. Anxiety-like responses induced by nitric oxide within the BNST in mice: role of the CRF1 and NMDA receptors. Horm Behav 79: 74-83.

Fendt M, Fanselow MS. 1999. The neuroanatomical and neurochemical basis of conditioned fear. Neurosci Biobehav Rev 23: 743-760.

Fendt M, Endres T, Apfelbach R. 2003. Temporary inactivation of the bed nucleus of the stria terminalis but not of the amygdala blocks freezing induced by trimethylthiazoline, a component of fox feces. J Neurosci 23: $23-28$.

Fendt M, Endres T, Lowry CA, Apfelbach R, McGregor IS. 2005. TMT-induced autonomic and behavioral changes and the neural basis of its processing. Neurosci Biobehav Rev 29: 1145-1156.

Flavin SA, Winder DG. 2013. Noradrenergic control of the bed nucleus of the stria terminalis in stress and reward. Neuropharmacology 70: 324-330.

Foa EB, Zinbarg R, Rothbaum BO. 1992. Uncontrollability and unpredictability in post-traumatic stress disorder: an animal model. Psychol Bull 112: 218-238.

Forray MI, Gysling K. 2004. Role of noradrenergic projections to the bed nucleus of the stria terminalis in the regulation of the hypothalamic-pituitary-adrenal axis. Brain Res Brain Res Rev 47: $145-160$.

Fox AS, Shelton SE, Oakes TR, Converse AK, Davidson RJ, Kalin NH. 2010. Orbitofrontal cortex lesions alter anxiety-related activity in the primate bed nucleus of stria terminalis. J Neurosci 30: 7023-7027.

Fox AS, Oler JA, Tromp do PM, Fudge JL, Kalin NH. 2015. Extending the amygdala in theories of threat processing. Trends Neurosci 38: 319-329.

Furini C, Myskiw J, Izquierdo I. 2014. The learning of fear extinction. Neurosci Biobehav Rev 47: 670-683.

Gewirtz JC, McNish KA, Davis M. 1998. Lesions of the bed nucleus of the stria terminalis block sensitization of the acoustic startle reflex produced by repeated stress but not fear potentiated startle. Prog Neuropsychopharmacol Biol Psychiatry 22: 625-648.

Giustino TF, Maren S. 2015. The role of the medial prefrontal cortex in the conditioning and extinction of fear. Front Behav Neurosci 9: 298.

Glangetas C, Girard D, Groc L, Marsicano G, Chaouloff F, Georges F. 2013. Stress switches cannabinoid type-1 (CB1) receptor-dependent plasticity from LTD to LTP in the bed nucleus of the stria terminalis. J Neurosci 33: 19657-19663.

Glangetas C, Massi L, Fois GR, Jalabert M, Girard D, Diana M, Yonehara K, Roska B, Xu C, Lüthi A, et al. 2017. NMDA-receptor-dependent plasticity in the bed nucleus of the stria terminalis triggers long-term anxiolysis. Nat Commun 8: 14456.

Gonzalez P, Martinez KG. 2014. The role of stress and fear in the development of mental disorders. Psychiatr Clin North Am 37: 535-546.

Goode TD, Maren S. 2014. Animal models of fear relapse. ILAR J 55: 246-258.

Goode TD, Kim JJ, Maren S. 2015a. Relapse of extinguished fear after exposure to a dangerous context is mitigated by testing in a safe context. Learn Mem 22: 170-178.

Goode TD, Kim JJ, Maren S. 2015b. Reversible inactivation of the bed nucleus of the stria terminalis prevents reinstatement but not renewal of extinguished fear. eNeuro 2: ENEURO.0037-15.2015.

Goosens KA. 2011. Hippocampal regulation of aversive memories. Curr Opin Neurobiol 21: 460-466.

Gorka AX, Torrisi S, Shackman AJ, Grillon C, Ernst M. 2017. Intrinsic functional connectivity of the central nucleus of the amygdala and bed nucleus of the stria terminalis. Neuroimage doi: 10.1016/j. neuroimage.2017.03.007

Goswami S, Rodríguez-Sierra O, Cascardi M, Paré D. 2013. Animal models of post-traumatic stress disorder: face validity. Front Neurosci 7: 89

Gourley SL, Taylor JR. 2016. Going and stopping: dichotomies in behavioral control by the prefrontal cortex. Nat Neurosci 19: 656-664.

Gray TS, Magnuson DJ. 1992. Peptide immunoreactive neurons in the amygdala and the bed nucleus of the stria terminalis project to the midbrain central gray in the rat. Peptides 13: 451-460.

Grillon C. 2002a. Associative learning deficits increase symptoms of anxiety in humans. Biol Psychiatry 51: 851-858.

Grillon C. 2002b. Startle reactivity and anxiety disorders: aversive conditioning, context, and neurobiology. Biol Psychiatry 52: 958-975.

Grillon C. 2008. Models and mechanisms of anxiety: evidence from startle studies. Psychopharmacology (Berl) 199: 421-437.

Gruene TM, Flick K, Stefano A, Shea SD, Shansky RM. 2015. Sexually divergent expression of active and passive conditioned fear responses. Elife 4: e11352.

Gungor NZ, Paré D. 2016. Functional heterogeneity in the bed nucleus of the stria terminalis. J Neurosci 36: 8038-8049.

Gungor NZ, Yamamoto R, Paré D. 2015. Optogenetic study of the projections from the bed nucleus of the stria terminalis to the central amygdala. J Neurophysiol 114: 2903-2911.

Gupta RR, Sen S, Diepenhorst LL, Rudick CN, Maren S. 2001. Estrogen modulates sexually dimorphic contextual fear conditioning and 
hippocampal long-term potentiation (LTP) in rats. Brain Res 888: 356-365.

Haaker J, Golkar A, Hermans D, Lonsdorf TB. 2014. A review on human reinstatement studies: an overview and methodological challenges. Learn Mem 21: 424-440.

Hammack SE, May V. 2015. Pituitary adenylate cyclase activating polypeptide in stress-related disorders: data convergence from animal and human studies. Biol Psychiatry 78: 167-177.

Hammack SE, Richey KJ, Watkins LR, Maier SF. 2004. Chemical lesion of the bed nucleus of the stria terminalis blocks the behavioral consequences of uncontrollable stress. Behav Neurosci 118: 443-448.

Hammack SE, Cheung J, Rhodes KM, Schutz KC, Falls WA, Braas KM, May V. 2009a. Chronic stress increases pituitary adenylate cyclase-activating peptide (PACAP) and brain-derived neurotrophic factor (BDNF) mRNA expression in the bed nucleus of the stria terminalis (BNST): roles for PACAP in anxiety-like behavior. Psychoneuroendocrinology 34: 833-843.

Hammack SE, Guo JD, Hazra R, Dabrowska J, Myers KM, Rainnie DG. 2009b. The response of neurons in the bed nucleus of the stria terminalis to serotonin: implications for anxiety. Prog Neuropsychopharmacol Biol Psychiatry 33: 1309-1320.

Hammack SE, Roman CW, Lezak KR, Kocho-Shellenberg M, Grimmig B, Falls WA, Braas K, May V. 2010. Roles for pituitary adenylate cyclase-activating peptide (PACAP) expression and signaling in the bed nucleus of the stria terminalis (BNST) in mediating the behavioral consequences of chronic stress. J Mol Neurosci 42: 327-340.

Hammack SE, Cooper MA, Lezak KR. 2012. Overlapping neurobiology of learned helplessness and conditioned defeat: implications for PTSD and mood disorders. Neuropharmacology 62: 565-575.

Hammack SE, Todd TP, Kocho-Schellenberg M, Bouton ME. 2015. Role of the bed nucleus of the stria terminalis in the acquisition of contextual fear at long or short context-shock intervals. Behav Neurosci 129: 673-678.

Hazra R, Guo JD, Dabrowska J, Rainnie DG. 2012. Differential distribution of serotonin receptor subtypes in BNST(ALG) neurons: modulation by unpredictable shock stress. Neuroscience 225: 9-21.

Herrmann MJ, Boehme S, Becker MP, Tupak SV, Guhn A, Schmidt B, Brinkmann L, Straube T. 2016. Phasic and sustained brain responses in the amygdala and the bed nucleus of the stria terminalis during threat anticipation. Hum Brain Mapp 37: 1091-1102.

Herry C, Bach DR, Esposito F, Di Salle F, Perrig WJ, Scheffler K, Lüthi A, Seifritz E. 2007. Processing of temporal unpredictability in human and animal amygdala. J Neurosci 27: 5958-5966.

Herry C, Ciocchi S, Senn V, Demmou L, Müller C, Lüthi A. 2008. Switching on and off fear by distinct neuronal circuits. Nature 454: 600-606.

Herry C, Ferraguti F, Singewald N, Letzkus JJ, Ehrlich I, Lüthi A. 2010. Neuronal circuits of fear extinction. Eur I Neurosci 31: 599-612.

Hines M, Davis FC, Coquelin A, Goy RW, Gorski RA. 1985. Sexually dimorphic regions in the medial preoptic area and the bed nucleus of the stria terminalis of the guinea pig brain: a description and an investigation of their relationship to gonadal steroids in adulthood. $J$ Neurosci 5: 40-47.

Hines M, Allen LS, Gorski RA. 1992. Sex differences in subregions of the medial nucleus of the amygdala and the bed nucleus of the stria terminalis of the rat. Brain Res 579: 321-326.

Hitchcock JM, Davis M. 1991. Efferent pathway of the amygdala involved in conditioned fear as measured with the fear-potentiated startle paradigm. Behav Neurosci 105: 826-842.

Holstege G, Meiners L, Tan K. 1985. Projections of the bed nucleus of the stria terminalis to the mesencephalon, pons, and medulla oblongata in the cat. Exp Brain Res 58: 379-391.

Hoover WB, Vertes RP. 2007. Anatomical analysis of afferent projections to the medial prefrontal cortex in the rat. Brain Struct Funct 212: 149-179.

Hott SC, Gomes FV, Fabri DR, Reis DG, Crestani CC, Correa FM, Resstel LB. 2012 . Both $\alpha 1$ - and $\beta 1$-adrenoceptors in the bed nucleus of the stria terminalis are involved in the expression of conditioned contextual fear. Br J Pharmacol 167: 207-221.

Hott SC, Gomes FV, Uliana DL, Vale GT, Tirapelli CR, Resstel LB. 2017. Bed nucleus of the stria terminalis NMDA receptors and nitric oxide modulate contextual fear conditioning in rats. Neuropharmacology 112: 135-143.

Izquierdo I, Furini CR, Myskiw JC. 2016. Fear memory. Physiol Rev 96: $695-750$

Jalabert M, Aston-Jones G, Herzog E, Manzoni O, Georges F. 2009. Role of the bed nucleus of the stria terminalis in the control of ventral tegmental area dopamine neurons. Prog Neuropsychopharmacol Biol Psychiatry 33: 1336-1346.

Jasnow AM, Lynch JF 3rd, Gilman TL, Riccio DC. Perspectives on fear generalization and its implications for emotional disorders. J Neurosci Res 95: 821-835.

Jennings JH, Sparta DR, Stamatakis AM, Ung RL, Pleil KE, Kash TL, Stuber GD. 2013. Distinct extended amygdala circuits for divergent motivational states. Nature 496: 224-228.
Ji J, Maren S. 2007. Hippocampal involvement in contextual modulation of fear extinction. Hippocampus 17: 749-758.

Jin J, Maren S. 2015a. Fear renewal preferentially activates ventral hippocampal neurons projecting to both amygdala and prefrontal cortex in rats. Sci Rep 5: 8388.

Jin J, Maren S. 2015b. Prefrontal-hippocampal interactions in memory and emotion. Front Syst Neurosci 9: 170.

Johansen JP, Cain CK, Ostroff LE, LeDoux JE. 2011. Molecular mechanisms of fear learning and memory. Cell 147: 509-524.

Johnson JB. 1923. Further contributions to the study of the evolution of the forebrain. J Comp Neurol 35: 337-481.

Jovanovic T, Ressler KJ. 2010. How the neurocircuitry and genetics of fear inhibition may inform our understanding of PTSD. Am J Psychiatry 167: 648-662.

Kash TL, Pleil KE, Marcinkiewcz CA, Lowery-Gionta EG, Crowley N, Mazzone C, Sugam J, Hardaway JA, McElligott ZA. 2015. Neuropeptide regulation of signaling and behavior in the BNST. Mol Cells 38: 1-13.

Kaufling J, Girard D, Maitre M, Leste-Lasserre T, Georges F. 2017. Species-specific diversity in the anatomical and physiological organization of the BNST-VTA pathway. Eur I Neurosci 45: 1230-1240.

Keifer OP Jr, Hurt RC, Ressler KJ, Marvar PJ. 2015. The physiology of fear: reconceptualizing the role of the central amygdala in fear learning. Physiology (Bethesda) 30: 389-401.

Kessler RC, Berglund P, Demler O, Jin R, Merikangas KR, Walters EE. 2005a. Lifetime prevalence and age-of-onset distributions of DSM-IV disorders in the National Comorbidity Survey Replication. Arch Gen Psychiatry 62: 593-602.

Kessler RC, Chiu WT, Demler O, Merikangas KR, Walters EE. 2005b. Prevalence, severity, and comorbidity of 12-month DSM-IV disorders in the National Comorbidity Survey Replication. Arch Gen Psychiatry 62: 617-627.

Kim JJ, Fanselow MS. 1992. Modality-specific retrograde amnesia of fear. Science 256: 675-677.

Kim SY, Adhikari A, Lee SY, Marshel JH, Kim CK, Mallory CS, Lo M, Pak S, Mattis J, Lim BK, et al. 2013. Diverging neural pathways assemble a behavioural state from separable features in anxiety. Nature 496: 219-223.

Klumpers F, Kroes MC, Heitland I, Everaerd D, Akkermans SE, Oosting RS, van Wingen G, Franke B, Kenemans JL, Fernández G, et al. 2015 Dorsomedial prefrontal cortex mediates the impact of serotonin transporter linked polymorphic region genotype on anticipatory threat reactions. Biol Psychiatry 78: 582-589.

Knapska E, Macias M, Mikosz M, Nowak A, Owczarek D, Wawrzyniak M, Pieprzyk M, Cymerman IA, Werka T, Sheng M, et al. 2012. Functional anatomy of neural circuits regulating fear and extinction. Proc Natl Acad Sci 109: 17093-17098.

Kocho-Schellenberg M, Lezak KR, Harris OM, Roelke E, Gick N, Choi I, Edwards S, Wasserman E, Toufexis DJ, Braas KM, et al. 2014. PACAP in the BNST produces anorexia and weight loss in male and female rats. Neuropsychopharmacology 39: 1614-1623.

Koob GF. 2009. Brain stress systems in the amygdala and addiction. Brain Res 1293: 61-75.

Krüger O, Shiozawa T, Kreifelts B, Scheffler K, Ethofer T. 2015. Three distinct fiber pathways of the bed nucleus of the stria terminalis to the amygdala and prefrontal cortex. Cortex 66: 60-68.

Laman-Maharg A, Trainor BC. 2017. Stress, sex, and motivated behaviors. $J$ Neurosci Res 95: 83-92.

Lange MD, Daldrup T, Remmers F, Szkudlarek HJ, Lesting J, Guggenhuber S, Ruehle S, Jüngling K, Seidenbecher T, Lutz B, et al. 2016. Cannabinoid CB1 receptors in distinct circuits of the extended amygdala determine fear responsiveness to unpredictable threat. Mol Psychiatry. doi: 10.1038/ mp.2016.156.

Lebow MA, Chen A. 2016. Overshadowed by the amygdala: the bed nucleus of the stria terminalis emerges as key to psychiatric disorders. Mol Psychiatry 21: 450-463.

LeDoux JE. 2000. Emotion circuits in the brain. Annu Rev Neurosci 23: $155-184$.

LeDoux JE. 2012. Rethinking the emotional brain. Neuron 73: 653-676.

LeDoux JE. 2014. Coming to terms with fear. Proc Natl Acad Sci 111: 2871-2878.

LeDoux JE. 2017. Semantics, surplus meaning, and the science of fear. Trends Cogn Sci 21: 303-306.

LeDoux JE, Brown R. 2017. A higher-order theory of emotional consciousness. Proc Natl Acad Sci 114: E2016-E2025.

LeDoux JE, Pine DS. 2016. Using neuroscience to help understand fear and anxiety: a two-system framework. Am I Psychiatry 173: 1083-1093.

LeDoux JE, Iwata J, Cicchetti P, Reis DJ. 1988. Different projections of the central amygdaloid nucleus mediate autonomic and behavioral correlates of conditioned fear. J Neurosci 8: 2517-2529.

Lee Y, Davis M. 1997. Role of the hippocampus, the bed nucleus of the stria terminalis, and the amygdala in the excitatory effect of 
corticotropin-releasing hormone on the acoustic startle reflex. J Neurosci 17: 6434-6446.

Lee Y, Fitz S, Johnson PL, Shekhar A. 2008. Repeated stimulation of CRF receptors in the BNST of rats selectively induces social but not panic-like anxiety. Neuropsychopharmacology 33: 2586-2594.

Levita L, Hammack SE, Mania I, Li XY, Davis M, Rainnie DG. 2004. 5-Hydroxytryptamine1A-like receptor activation in the bed nucleus of the stria terminalis: electrophysiological and behavioral studies. Neuroscience 128: 583-596.

Lino-de-Oliveira C, Sales AJ, Del Bel EA, Silveira MC, Guimarães FS. 2001. Effects of acute and chronic fluoxetine treatments on restraint stress-induced Fos expression. Brain Res Bull 55: 747-754.

Lonsdorf TB, Menz MM, Andreatta M, Fullana MA, Golkar A, Haaker J, Heitland I, Hermann A, Kuhn M, Kruse O, et al. 2017. Don't fear 'fear conditioning': methodological considerations for the design and analysis of studies on human fear acquisition, extinction, and return of fear. Neurosci Biobehav Rev 77: 247-285.

Luyck K, Luyten L. 2015. Can electrical stimulation of the human bed nucleus of the stria terminalis reduce contextual anxiety? An unanswered question. Front Behav Neurosci 9: 69.

Luyck K, Tambuyzer T, Deprez M, Rangarajan J, Nuttin B, Luyten L. 2017. Electrical stimulation of the bed nucleus of the stria terminalis reduces anxiety in a rat model. Transl Psychiatry 7: e1033.

Luyten L, Casteels C, Vansteenwegen D, van Kuyck K, Koole M, Van Laere K, Nuttin B. 2012. Micro-positron emission tomography imaging of rat brain metabolism during expression of contextual conditioning. $J$ Neurosci 32: 254-263.

Mahan AL, Ressler KJ. 2012. Fear conditioning, synaptic plasticity and the amygdala: implications for posttraumatic stress disorder. Trends Neurosci 35: $24-35$.

Mantsch JR, Baker DA, Funk D, Lê AD, Shaham Y. 2016. Stress-induced reinstatement of drug seeking: 20 years of progress. Neuropsychopharmacology 41: 335-356.

Marcinkiewcz CA, Mazzone CM, D'Agostino G, Halladay LR, Hardaway JA, DiBerto JF, Navarro M, Burnham N, Cristiano C, Dorrier CE, et al. 2016. Serotonin engages an anxiety and fear-promoting circuit in the extended amygdala. Nature 537: 97-101.

Maren S. 1999a. Long-term potentiation in the amygdala: a mechanism for emotional learning and memory. Trends Neurosci 22: 561-567.

Maren S. 1999b. Neurotoxic basolateral amygdala lesions impair learning and memory but not the performance of conditional fear in rats. $J$ Neurosci 19: 8696-8703.

Maren S. 2001. Neurobiology of Pavlovian fear conditioning. Аnnu Rev Neurosci 23: 897-931.

Maren S. 2005. Synaptic mechanisms of associative memory in the amygdala. Neuron 47: 783-786.

Maren S. 2011. Seeking a spotless mind: extinction, deconsolidation, and erasure of fear memory. Neuron 70: 830-845.

Maren S, Holmes A. 2016. Stress and fear extinction. Neuropsychopharmacology 41: 58-79.

Maren S, Quirk GJ. 2004. Neuronal signalling of fear memory. Nat Rev Neurosci 5: 844-852.

Maren S, De Oca B, Fanselow MS. 1994. Sex differences in hippocampal long-term potentiation (LTP) and Pavlovian fear conditioning in rats: positive correlation between LTP and contextual learning. Brain Res 661: 25-34.

Maren S, Aharonov G, Stote DL, Fanselow MS. 1996. N-methyl-D-aspartate receptors in the basolateral amygdala are required for both acquisition and expression of conditional fear in rats. Behav Neurosci 110: $1365-1374$.

Maren S, Anagnostaras SG, Fanselow MS. 1998. The startled seahorse: is the hippocampus necessary for contextual fear conditioning? Trends Cogn Sci 2: $39-41$.

Maren S, Phan KL, Liberzon I. 2013. The contextual brain: implications for fear conditioning, extinction and psychopathology. Nat Rev Neurosci 14: $417-428$.

Markus EJ, Zecevic M. 1997. Sex differences and estrous cycle changes in hippocampus-dependent fear conditioning. Psychobiology 25: 246-252.

Mazzone CM, Pati D, Michaelides M, DiBerto J, Fox JH, Tipton G, Anderson C, Duffy K, McKlveen JM, Hardaway JA, et al. 2016. Acute engagement of Gq-mediated signaling in the bed nucleus of the stria terminalis induces anxiety-like behavior. Mol Psychiatry. doi: 10.1038/ mp.2016.218.

McConnell BL, Miller RR. 2014. Associative accounts of recovery-from-extinction effects. Learn Motiv 46: 1-15.

McDonald AJ, Shammah-Lagnado SJ, Shi C, Davis M. 1999. Cortical afferents to the extended amygdala. Ann N Y Acad Sci 877: 309-338.

McElligott ZA, Fox ME, Walsh PL, Urban DJ, Ferrel MS, Roth BL, Wightman RM. 2013. Noradrenergic synaptic function in the bed nucleus of the stria terminalis varies in animal models of anxiety and addiction. Neuropsychopharmacology 38: 1665-1673.
McEwen BS. 2012. Brain on stress: how the social environment gets under the skin. Proc Natl Acad Sci 109: 17180-17185.

McLemore S, Crown ED, Meagher MW, Grau JW. 1999. Shock-induced hyperalgesia: II. Role of the dorsolateral periaqueductal gray. Behav Neurosci 113: 539-549.

Meloni EG, Jackson A, Gerety LP, Cohen BM, Carlezon WA Jr. 2006. Role of the bed nucleus of the stria terminalis (BST) in the expression of conditioned fear. Ann N Y Acad Sci 1071: 538-541.

Milad MR, Quirk GJ. 2012. Fear extinction as a model for translational neuroscience: ten years of progress. Аппи Rev Psychol 63: 129-151.

Minami M, Ide S. 2015. How does pain induce negative emotion? Role of the bed nucleus of the stria terminalis in pain-induced place aversion. Curr Mol Med 15: 184-190.

Mobbs D, Yu R, Rowe JB, Eich H, FeldmanHall O, Dalgleish T. 2010. Neural activity associated with monitoring the oscillating threat value of a tarantula. Proc Natl Acad Sci 107: 20582-20586.

Morris RW, Furlong TM, Westbrook RF. 2005. Recent exposure to a dangerous context impairs extinction and reinstates lost fear reactions. $J$ Exp Psychol Anim Behav Process 31: 40-55.

Motzkin JC, Philippi CL, Oler JA, Kalin NH, Baskaya MK, Koenigs M. 2015. Ventromedial prefrontal cortex damage alters resting blood flow to the bed nucleus of stria terminalis. Cortex 64: 281-288.

Myers KM, Davis M. 2002. Behavioral and neural analysis of extinction. Neuron 36: $567-584$.

Nagaya N, Acca GM, Maren S. 2015. Allopregnanolone in the bed nucleus of the stria terminalis modulates contextual fear in rats. Front Behav Neurosci 9: 205.

Nagy FZ, Paré D. 2008. Timing of impulses from the central amygdala and bed nucleus of the stria terminalis to the brain stem. J Neurophysiol 100: 3429-3436.

Naka T, Ide S, Nakako T, Hirata M, Majima Y, Deyama S, Takeda H, Yoshioka M, Minami M. 2013. Activation of $\beta$-adrenoceptors in the bed nucleus of the stria terminalis induces food intake reduction and anxiety-like behaviors. Neuropharmacology 67: 326-330.

Oler JA, Tromp DP, Fox AS, Kovner R, Davidson RJ, Alexander AL, McFarlin DR, Birn RM, E Berg B, deCampo DM, et al. 2017. Connectivity between the central nucleus of the amygdala and the bed nucleus of the stria terminalis in the non-human primate: neuronal tract tracing and developmental neuroimaging studies. Brain Struct Funct 222: 21-39.

Orsini CA, Maren S. 2012. Neural and cellular mechanisms of fear and extinction memory formation. Neurosci Biobehav Rev 36: 1773-1802.

Orsini CA, Kim JH, Knapska E, Maren S. 2011. Hippocampal and prefrontal projections to the basal amygdala mediate contextual regulation of fear after extinction. J Neurosci 31: 17269-17277.

Passerin AM, Cano G, Rabin BS, Delano BA, Napier JK, Sved AF. 2000. Role of locus coeruleus in foot shock-evoked Fos expression in rat brain. Neuroscience 101: 1071-1082.

Pavlov IP. 1927. Conditioned reflexes: an investigation of the physiological activity of the cerebral cortex. Dover Publications, New York.

Pedersen WS, Muftuler LT, Larson CL. 2017. Disentangling the effects of novelty, valence and trait anxiety in the bed nucleus of the stria terminalis, amygdala and hippocampus with high resolution 7T fMRI. Neuroimage 156: 293-301.

Pellman BA, Schuessler BP, Tellakat M, Kim JJ. 2017. Sexually dimorphic risk mitigation strategies in rats. eNeuro 4: ENEURO.0288-16.2017.

Perusini JN, Fanselow MS. 2015. Neurobehavioral perspectives on the distinction between fear and anxiety. Learn Mem 22: 417-425.

Petrulis A. 2013. Chemosignals and hormones in the neural control of mammalian sexual behavior. Front Neuroendocrinol 34: 255-267.

Phelps EA, LeDoux JE. 2005. Contributions of the amygdala to emotion processing: from animal models to human behavior. Neuron 48 : $175-187$.

Phillips RG, LeDoux JE. 1992. Differential contribution of amygdala and hippocampus to cued and contextual fear conditioning. Behav Neurosci 106: 274 .

Poulos AM, Ponnusamy R, Dong HW, Fanselow MS. 2010. Compensation in the neural circuitry of fear conditioning awakens learning circuits in the bed nuclei of the stria terminalis. Proc Natl Acad Sci 107: 14881-14886.

Pryce CS, Lehmann J, Feldon J. 1999. Effect of sex on fear conditioning is similar for context and discrete CS in Wistar, Lewis and Fischer rat strains. Pharmacol Biochem Behav 64: 753-759.

Quirk GJ, Mueller D. 2008. Neural mechanisms of extinction learning and retrieval. Neuropsychopharmacology 33: 56-72.

Quirk GJ, Garcia R, González-Lima F. 2006. Prefrontal mechanisms in extinction of conditioned fear. Biol Psychiatry 60: 337-343.

Radke AK. 2009. The role of the bed nucleus of the stria terminalis in learning to fear. J Neurosci 29: 15351-15352.

Ranjan V, Singh S, Siddiqui SA, Tripathi S, Khan MY, Prakash A. 2017. Differential histone acetylation in sub-regions of bed nucleus of the stria terminalis underlies fear consolidation and extinction. Psychiatry Investig 14: 350-359. 
Ravinder S, Burghardt NS, Brodsky R, Bauer EP, Chattarji S. 2013. A role for the extended amygdala in the fear-enhancing effects of acute selective serotonin reuptake inhibitor treatment. Transl Psychiatry 3: e209.

Reichard RA, Subramanian S, Desta MT, Sura T, Becker ML, Ghobadi CW, Parsley KP, Zahm DS. 2017. Abundant collateralization of temporal lobe projections to the accumbens, bed nucleus of stria terminalis, central amygdala and lateral septum. Brain Struct Funct 222: 1971-1988.

Reisiger AR, Kaufling J, Manzoni O, Cador M, Georges F, Caillé S. 2014. Nicotine self-administration induces CB1-dependent LTP in the bed nucleus of the stria terminalis. J Neurosci 34: 4285-4292.

Rescorla RA. 1988. Pavlovian conditioning. It's not what you think it is. Am Psychol 43: 151-160.

Rescorla RA. 2004. Spontaneous recovery. Learn Mem 11: 501-509.

Rescorla RA, Heth CD. 1975. Reinstatement of fear to an extinguished conditioned stimulus. J Exp Psychol Anim Behav Process 1: 88-96.

Rescorla RA, Wagner AR. 1972. A theory of Pavlovian conditioning: variations in the effectiveness of reinforcement and nonreinforcement. In (ed. Black AH, Prokasy WF) Classical conditioning II: current research and theory (pp. p64-99). Appleton-Century-Crofts, New York.

Resstel LB, Alves FH, Reis DG, Crestani CC, Correa FM, Guimaraes FS. 2008. Anxiolytic-like effects induced by acute reversible inactivation of the bed nucleus of stria terminalis. Neuroscience 154: 869-876.

Reynolds SM, Zahm DS. 2005. Specificity in the projections of prefrontal and insular cortex to ventral striatopallidum and the extended amygdala. J Neurosci 25: 11757-11767.

Robinson OJ, Overstreet C, Allen PS, Pine DS, Grillon C. 2012. Acute tryptophan depletion increases translational indices of anxiety but not fear: serotonergic modulation of the bed nucleus of the stria terminalis? Neuropsychopharmacology 37: 1963-1971.

Rodríguez-Sierra OE, Goswami S, Turesson HK, Pare D. 2016. Altered responsiveness of BNST and amygdala neurons in trauma-induced anxiety. Transl Psychiatry 6: e857.

Rogan MT, Stäubli UV, LeDoux JE. 1997. Fear conditioning induces associative long-term potentiation in the amygdala. Nature 390: 604-607.

Rosen JB, Asok A, Chakraborty T. 2015. The smell of fear: innate threat of 2,5-dihydro-2,4,5-trimethylthiazoline, a single molecule component of a predator odor. Front Neurosci 9: 292.

Rozeske RR, Valerio S, Chaudun F, Herry C. 2015. Prefrontal neuronal circuits of contextual fear conditioning. Genes Brain Behav 14: 22-36.

Rudy JW, Huff NC, Matus-Amat P. 2004. Understanding contextual fear conditioning: insights from a two-process model. Neurosci Biobehav Rev 28: $675-685$.

Sahuque LL, Kullberg EF, Mcgeehan AJ, Kinder JR, Hicks MP, Blanton MG, Janak PH, Olive MF. 2006. Anxiogenic and aversive effects of corticotropin-releasing factor (CRF) in the bed nucleus of the stria terminalis in the rat: role of CRF receptor subtypes. Psychopharmacology (Berl) 186: 122-132.

Sanford CA, Soden ME, Baird MA, Miller SM, Schulkin J, Palmiter RD, Clark M, Zweifel LS. 2017. A central amygdala CRF circuit facilitates learning about weak threats. Neuron 93: 164-178.

Scharfenort R, Lonsdorf TB. 2016. Neural correlates of and proccesses underlying generalized and differential return of fear. Soc Cogn Affect Neurosci 11: 612-620.

Schlund MW, Hudgins CD, Magee S, Dymond S. 2013. Neuroimaging the temporal dynamics of human avoidance to sustained threat. Behav Brain Res 257: 148-155.

Schmitz A, Grillon C. 2012. Assessing fear and anxiety in humans using the threat of predictable and unpredictable aversive events (the NPU-threat test). Nat Protoc 7: 527-532.

Seidenbecher T, Remmes J, Daldrup T, Lesting J, Pape HC. 2016. Distinct state anxiety after predictable and unpredictable fear training in mice. Behav Brain Res 304: 20-23.

Senn V, Wolff SB, Herry C, Grenier F, Ehrlich I, Gründemann J, Fadok JP, Müller C, Letzkus JJ, Lüthi A. 2014. Long-range connectivity defines behavioral specificity of amygdala neurons. Neuron 81: $428-437$

Shackman AJ, Fox AS. 2016. Contributions of the central extended amygdala to fear and anxiety. J Neurosci 36: 8050-8063.

Shaham Y, Shalev U, Lu L, De Wit H, Stewart J. 2003. The reinstatement model of drug relapse: history, methodology and major findings. Psychopharmacology (Berl) 168: 3-20.

Shalev U, Morales M, Hope B, Yap J, Shaham Y. 2001. Time-dependent changes in extinction behavior and stress-induced reinstatement of drug seeking following withdrawal from heroin in rats. Psychopharmacology (Berl) 156: 98-107.

Silberman Y, Winder DG. 2013. Emerging role for corticotropin releasing factor signaling in the bed nucleus of the stria terminalis at the intersection of stress and reward. Front Psychiatry 4: 42.

Sink KS, Walker DL, Yang Y, Davis M. 2011. Calcitonin gene-related peptide in the bed nucleus of the stria terminalis produces an anxiety-like pattern of behavior and increases neural activation in anxiety-related structures. J Neurosci 31: 1802-1810.

Sink KS, Davis M, Walker DL. 2013a. CGRP antagonist infused into the bed nucleus of the stria terminalis impairs the acquisition and expression of context but not discretely cued fear. Learn Mem 20: 730-739.

Sink KS, Chung A, Ressler KJ, Davis M, Walker DL. 2013b. Anxiogenic effects of CGRP within the BNST may be mediated by CRF acting at BNST CRFR1 receptors. Behav Brain Res 243: 286-293.

Sladky R, Geissberger N, Pfabigan DM, Kraus C, Tik M, Woletz M, Paul K, Vanicek T, Auer B, Kranz GS, et al. 2017. Unsmoothed functional MRI of the human amygdala and bed nucleus of the stria terminalis during processing of emotional faces. Neuroimage. doi: $10.1016 / \mathrm{j}$. neuroimage.2016.12.024.

Somerville LH, Whalen PJ, Kelley WM. 2010. Human bed nucleus of the stria terminalis indexes hypervigilant threat monitoring. Biol Psychiatry 68: $416-424$.

Spencer SJ, Buller KM, Day TA. 2005. Medial prefrontal cortex control of the paraventricular hypothalamic nucleus response to psychological stress: possible role of the bed nucleus of the stria terminalis. J Comp Neurol 481: $363-376$.

Stamatakis AM, Sparta DR, Jennings JH, McElligott ZA, Decot H, Stuber GD. 2014. Amygdala and bed nucleus of the stria terminalis circuitry: implications for addiction-related behaviors. Neuropharmacology 76(Pt B): $320-328$.

Sullivan GM, Apergis J, Bush DE, Johnson LR, Hou M, Ledoux JE. 2004. Lesions in the bed nucleus of the stria terminalis disrupt corticosterone and freezing responses elicited by a contextual but not by a specific cue-conditioned fear stimulus. Neuroscience 128: 7-14.

Sun N, Roberts L, Cassell MD. 1991. Rat central amygdaloid nucleus projections to the bed nucleus of the stria terminalis. Brain Res Bull 27: 651-662.

Takahashi LK. 2014. Olfactory systems and neural circuits that modulate predator odor fear. Front Behav Neurosci 8: 72.

Theiss JD, Ridgewell C, McHugo M, Heckers S, Blackford JU. 2017. Manual segmentation of the human bed nucleus of the stria terminalis using $3 \mathrm{~T}$ MRI. Neuroimage 146: 288-292.

Torrisi S, O'Connell K, Davis A, Reynolds R, Balderston N, Fudge JL, Grillon C, Ernst M. 2015. Resting state connectivity of the bed nucleus of the stria terminalis at ultra-high field. Hum Brain Mapp 36: 4076-4088.

Tovote P, Fadok JP, Lüthi A. 2015. Neuronal circuits for fear and anxiety. Nat Rev Neurosci 16: 317-331.

Treit D, Aujla H, Menard J. 1998. Does the bed nucleus of the stria terminalis mediate fear behaviors? Behav Neurosci 112: 379-386.

Turesson HK, Rodríguez-Sierra OE, Paré D. 2013. Intrinsic connections in the anterior part of the bed nucleus of the stria terminalis. J Neurophysiol 109: $2438-2450$.

Urcelay GP, Miller RR. 2014. The functions of contexts in associative learning. Behav Processes 104: 2-12.

VanElzakker MB, Dahlgren MK, Davis FC, Dubois S, Shin LM. 2014. From Pavlov to PTSD: the extinction of conditioned fear in rodents, humans, and anxiety disorders. Neurobiol Learn Mem 113: 3-18.

Vertes RP. 2004. Differential projections of the infralimbic and prelimbic cortex in the rat. Synapse 51: 32-58.

Vervliet B, Craske MG, Hermans D. 2013. Fear extinction and relapse: state of the art. Annu Rev Clin Psychol 9: 215-248.

Vranjkovic O, Pina M, Kash TL, Winder DG. 2017. The bed nucleus of the stria terminalis in drug-associated behavior and affect: a circuit-based perspective. Neuropharmacology 122: 100-106.

Waddell J, Bouton ME, Falls WA. 2008. Central CRF receptor antagonist a-helical CRF9-41 blocks reinstatement of extinguished fear: the role of the bed nucleus of the stria terminalis. Behav Neurosci 122: 1061-1069.

Waddell J, Morris RW, Bouton ME. 2006. Effects of bed nucleus of the stria terminalis lesions on conditioned anxiety: aversive conditioning with long-duration conditional stimuli and reinstatement of extinguished fear. Behav Neurosci 120: 324-336.

Walker DL, Davis M. 1997. Double dissociation between the involvement of the bed nucleus of the stria terminalis and the central nucleus of the amygdala in startle increases produced by conditioned versus unconditioned fear. J Neurosci 17: 9375-9383.

Walker DL, Davis M. 2008. Role of the extended amygdala in short-duration versus sustained fear: a tribute to Dr. Lennart Heimer. Brain Struct Funct 213: 29-42.

Walker DL, Miles LA, Davis M. 2009. Selective participation of the bed nucleus of the stria terminalis and CRF in sustained anxiety-like versus phasic fear-like responses. Prog Neuropsychopharmacol Biol Psychiatry 33: 1291-1308.

Waraczynski M. 2016. Toward a systems-oriented approach to the role of the extended amygdala in adaptive responding. Neurosci Biobehav Rev 68: 177-194. 
Weller KL, Smith DA. 1982. Afferent connections to the bed nucleus of the stria terminalis. Brain Res 232: 255-270.

Westbrook RF, Iordanova M, McNally G, Richardson R, Harris JA.

2002. Reinstatement of fear to an extinguished conditioned stimulus: two roles for context. J Exp Psychol Anim Behav Process 28: 97-110.

Whiteford HA, Degenhardt L, Rehm J, Baxter AJ, Ferrari AJ, Erskine HE, Charlson FJ, Norman RE, Flaxman AD, Johns N, et al. 2013. Global burden of disease attributable to mental and substance use disorders: findings from the Global Burden of Disease Study 2010. Lancet 382: $1575-1586$.

Xu C, Krabbe S, Gründemann J, Botta P, Fadok JP, Osakada F, Saur D, Grewe BF, Schnitzer MJ, Callaway EM, et al. 2016. Distinct hippocampal pathways mediate dissociable roles of context in memory retrieval. Cell 167: 961-972.e16.

Ye X, Kapeller-Libermann D, Travaglia A, Inda MC, Alberini CM. 2017. Direct dorsal hippocampal-prelimbic cortex connections strengthen fear memories. Nat Neurosci 20: 52-61.

Zimmerman JM, Maren S. 2011. The bed nucleus of the stria terminalis is required for the expression of contextual but not auditory freezing in rats with basolateral amygdala lesions. Neurobiol Learn Mem 95: 199-205.

Received April 23, 2017; accepted in revised form June 30, 2017. 


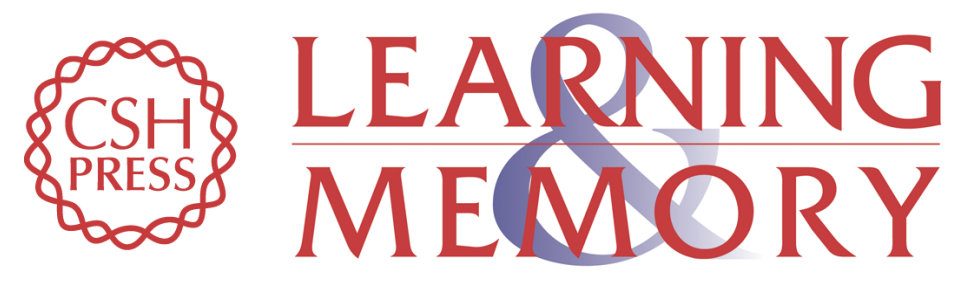

\section{Role of the bed nucleus of the stria terminalis in aversive learning and memory}

Travis D. Goode and Stephen Maren

Learn. Mem. 2017, 24:

Access the most recent version at doi:10.1101/Im.044206.116

References This article cites 273 articles, 37 of which can be accessed free at: http://learnmem.cshlp.org/content/24/9/480.full.html\#ref-list-1

Creative This article is distributed exclusively by Cold Spring Harbor Laboratory Press for the Commons License first 12 months after the full-issue publication date (see

http://learnmem.cshlp.org/site/misc/terms.xhtml). After 12 months, it is available under a Creative Commons License (Attribution-NonCommercial 4.0 International), as described at http://creativecommons.org/licenses/by-nc/4.0/.

Email Alerting Receive free email alerts when new articles cite this article - sign up in the box at the Service top right corner of the article or click here. 